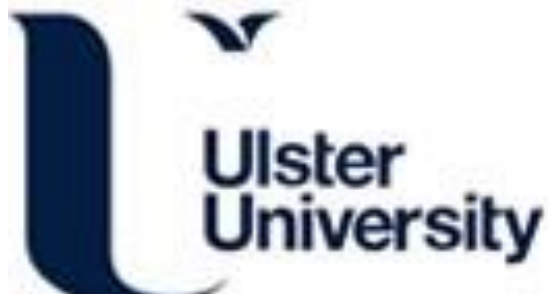

\section{Power generation from biomass in a small CFBC plant compared with biomass co- fired with coal in a large CFBC}

Mcllveen-Wright, D., Rezvani, S., Huang, Y., \& Hewitt, NJ. (2007). Power generation from biomass in a small CFBC plant compared with biomass co-fired with coal in a large CFBC. International Journal of Ambient Energy, 28(3), 143-150.

Link to publication record in Ulster University Research Portal

\section{Published in:}

International Journal of Ambient Energy

Publication Status:

Published (in print/issue): 01/07/2007

\section{Document Version \\ Author Accepted version}

\section{General rights}

Copyright for the publications made accessible via Ulster University's Research Portal is retained by the author(s) and / or other copyright owners and it is a condition of accessing these publications that users recognise and abide by the legal requirements associated with these rights.

\section{Take down policy}

The Research Portal is Ulster University's institutional repository that provides access to Ulster's research outputs. Every effort has been made to ensure that content in the Research Portal does not infringe any person's rights, or applicable UK laws. If you discover content in the Research Portal that you believe breaches copyright or violates any law, please contact pure-support@ulster.ac.uk. 


\section{Power}

generation
from biomass

in a small

CFBC plant

compared with

biomass co-

fired with coal

in a large

CFBC

\author{
D. R. Mcllveen-Wright*, \\ S. Rezvani**, Y. Huang*** and \\ N. J. Hewittt
}

\section{SYNOPSIS}

Biomass is one of the renewable energy sources which is not intermittent, location-dependent or very difficult to store. If grown sustainably, biomass can be considered to be $\mathrm{CO}_{2}$ neutral.

The use of biomass for power generation is also considered to be important in increasing the electricity output from renewable energy sources.

However, power plants dedicated to the use of biomass fuel are not in widespread use and the acceptance of this fuel and development of the infrastructure for biomass production and transportation remain in their infancy. If small ratios of biomass can be co-fired with coal in large-scale conventional power plants, without significant technical, environmental or economic penalties, it could lead to a greater demand for biomass and so stimulate the industry.

In this study a 80 MWth Circulating Fluidised Bed Combustion (CFBC) plant, fuelled by biomass only, and a large-scale 1000 MWth CFBC, co-fired with coal and $8 \%$ biomass, and the same large CFBC system, fired only with coal, are modelled using the ECLIPSE process simulation package and their technical, environmental and economic properties analysed and compared.

The co-firing of biomass with coal was found to have little effect on the large-scale CFBC system, when a small ratio of biomass is used. The large scale system was found to have higher efficiency, lower $\mathrm{CO}_{2}$ emissions and lower breakeven electricity selling price than the small biomass-fuelled CFBC.

Co-firing of biomass with coal could be a promising way of promoting the production, use and acceptance of biomass as a fuel in electricity generation.

\section{NTRODUCTION}

The co-combustion of coal and biomass has received widespread interest for some time as a means of conserving coal reserves and reducing net $\mathrm{CO}_{2}$ emissions [1]. A life cycle assessment of several coal combustion scenarios (coal-based electricity generation, coal and biomass co-firing, post-combustion $\mathrm{CO}_{2}$ capture and coal ash valorisation) with biomass combustion asserted that co-firing was the most effective method of reducing $\mathrm{CO}_{2}$ emissions [2]. Several other environmental advantages have been reported e.g. co-firing high-sulphur bituminous coal with $20 \%$ straw gave a net reduction in $\mathrm{NO}$ and $\mathrm{SO}_{2}$ emissions [3]; lower NO, emissions may be found during co-combustion, since there is high volatile content in biomass, the nitrogen in which preferentially forms $\mathrm{NH}_{3}$ as opposed to $\mathrm{HCN}$ which is formed preferentially by nitrogen from coal [4]; and the primary reactions of thermal decomposition of biomass fuels are not significantly affected by the presence of coal, which itself does

\footnotetext{
D. R. Mcllveen-Wright, Centre for Sustainable Technologies CST), Faculty of Art Design and the Built Environment, University of Ulster, Whiteabbey, BT37 OQB, Northern Ireland, E-mail: dr.mcilveen-wright@ulster.ac.uk.

S. Rezvani, Centre for Sustainable Technologies (CST), Faculty of Art Design and the Built Environment, University of "' Y. Huang, Centre for Sustainable Technologies (CST), Faculty of Art Design and the Built Environment, University of Ulster, Whiteabbey, BT37 OQB, Northern Ireland, UK.

t N. J. Hewitt, Centre for Sustainable Technologies (CST), Faculty of Art Design and the Built Environment, University of Ulster, Whiteabbey, BT37 OQB, Northern Ireland, UK.

C Ambient Press Limited 2007
} 